\title{
PENGEMBANGAN ORGANIZATIONAL CITIZENSHIP BEHAVIOR (OCB) MELALUI PENINGKATAN WORKPLACE SPIRITUALITY DAN ISLAMIC WORK ETHICS
}

\author{
Sri Hindah Pudjihastuti ${ }^{1}$, Endang Dwi Astuti ${ }^{2}$ \\ UNISSULA Semarang ${ }^{1,2}$
}

Email koresponden: $\underline{\text { srihindah@unissula.ac.id }}{ }^{1}$

\begin{abstract}
The purpose of the study was to determine the impact of workplace spirituality (organizational spirituality and individual spirituality) on organizational citizenship behavior (OCB), with Islamic work ethics as an intervening variable. The population in this study are professionals consisting of teaching staff and company managers. The respondents who participated were 200 professionals. The results showed that the organizational spiritual dimension has significant influence on Islamic work ethics and OCB. In addition, Islamic work ethics has a significant influence on $O C B$. However, the dimensions of individual spirituality have no influence on Islamic work ethics or OCB. The implication of the results of the study shows the important role of Islamic work ethics in mediating the relationship between workplace spirituality and $O C B$. In addition, $O C B$ development for professionals can be done with a spirituality approach that is organizational in nature and also by increasing Islamic work ethics.
\end{abstract}

Keywords: organizational spirituality, individual spirituality, Islamic work ethics, $O C B$

\section{A. PENDAHULUAN}

Nilai-nilai spiritualitas saat ini menjadi perhatian yang sangat serius, terutama hubungan antara nilai-nilai dengan etika bisnis. Semakin meningkatnya kajian tentang kaitan antara nilainilai spiritualitas, etika, dan kinerja merefleksikan tingkat interest para akademisi yang semakin meningkat (Kolodinsky, Giacalone, \& Jurkiewicz, 2008). Kebutuhan untuk pemimpin organisasi untuk memperhatikan nilai-nilai spiritualitas nampaknya belum begitu besar. Pemimpin selalu berusaha untuk mencari strategi agar nilai-nilai spiritual berdampak positif kepada anggota organisasi. Sebagai hasilnya, karyawan membutuhkan koneksi, makna, maksud, mementingkan orang lain, kebajikan, pengasuhan, dan harapan dalam pekerjaan dan tempat kerjanya (Fry, Vitucci, \& Cedillo, 2005).

Kajian tentang spiritualitas di tempat kerja telah dilakukan oleh beberapa peneliti lebih dari sepuluh tahun yang lalu (Howard, 2002; Giacolane and Jurkiewicz, 2003). Akhirnya, pertumbuhan kajian tentang spirituality dalam perusahaan dan dunia bisnis semakin baik. Beberapa perusahaan menggabungkan spirituality ke dalam strategi mereka dalam kerangka corporate social responsibility. Sebagai contoh, Anita Roddick, penemu Body Shop, komitmen 
untuk berkontribusi terhadap Glasgow melalui proyek pertanggungjawaban sosial melalui kontribusinya kepada masalah pengangguran, kriminal, dan urbanisasi. Banyak perusahaan juga membumikan nilai-nilai dan prinsip-prinsip spiritual yang berkomitmen terhadap tanggungjawab sosial dan pelayanan masyarakat. Contoh ini membuktikan bahwa organisasi dapat menggabungkan antara spirituality dan tanggungjawab sosial ke dalam misinya.

Terdapat proposisi dimana spiritualitas (employee well-being, sense of meaning and purpose, and sense of community and interconnectedness) dapat meningkatkan kesejahteraan karyawan secara umum (Karakas, 2010). Hubungan antara spirituality dan kinerja telah dikaji dan menghasilkan tiga proposisi (Karakas, 2010). Proposisi pertama; spirituality meningkatkan kesejahteraan secara umum, proposisi kedua; spirituality memberikan kepada karayawan dan manajer makna tujuan kerja yang mendalam, dan proposisi ketiga spirituality memberikan karyawan rasa kebersamaan dan keterkaitan, peningkatan kecintaan karyawan, loyalitas dan rasa memiliki terhadap organisasi. Spirituality dapat mencapai kesejahteraan karyawan melalui peningkatan moral, komitment dan produktivitas, mengurangi stres, dan kejenuhan.

Dari sisi kebermaknaan, spirituality memberikan karyawan dan manager rasa kebersamaan dan keterkaitan, peningkatan kecintaan mereka, loyalitas dan rasa memiliki terhadap organisasi. Untuk dapat bertahan dalam lingkungan yang kompetitif, setiap perusahaan membutuhkan pencapaian laba yang tinggi dan pangsa pasar yang besar. Tekanan ini menyebabkan perusahaan menetapkan target yang sangat tinggi dan tidak realistik kepada karyawan, dan kaitannya untuk mencapai target, karyawan ditekan untuk bekerja lembur dan di hari libur. Jumlah jam kerja yang panjang dan beban kerja yang berlebihan akan stress pada karyawan, dan menyebabkan kinerja yang buruk, interaksi keluarga dan masyarakat yang buruk, serta kesehatan yang buruk. Kesemuanya itu dapat berakibat mengurangi kepuasan kerja, dan dapat meningkatkan absensi dan turnover karyawan. Berbagai dimensi spirituality sangatlah penting, namun demikian dimensi nilai-nilai organisasi dan a sense of community merupakan terminologi yang sangat penting terhadap kepuasan kerja pada level karyawan (Gupta et.al, 2014).

Hasil penelitian pengaruh workplace spirituality dengan kepuasan karyawan sebagai variabel dependen menunjukkan pengaruh yang positif dan signifikan (Gupta et.al, 2014). Namun demikian, nilai koefisien determinasi masing-masing dimensi workplace spirituality menunjukkan koefisien yang masih kecil. Dimensi meaningful work 0,280, dimensi sense of community 0.451 , dimensi organizational value 0,503 , dan dimensi compassion 0,347 . Temuan ini menunjukkan bahwa kontribusi variabel independen terhadap variabel masih sangat kecil. 
Pengaruh yang tinggi terhadap job performance ditunjukkan oleh dimensi sense of belonging dan organizational value. Perusahaan perlu melakukan perubahan dengan cultural transformation dengan mengaplikasikan praktek-praktek spiritual seperti meditasi, pembelajaran spiritualitas, silence before meeting, respek terhadap agama dari setiap karyawan, perilaku tidak membedakan antara karyawan senior dengan karyawan junior, dan penghapusan level hirarki untuk menciptakan rasa kebersamaan.

Untuk penelitian mendatang perlu dimasukkan varibel moderating, seperti absenteeism, organizational citizenship behavior, turnover intention, dan organizational commitment. Aspek kepercayaan, perceived organizational support, positive emotion, dan stres dapat juga digunakan sebagai variabel intervening (Gupta et.al, 2014). Kolodinsky, Giacalone, \& Jurkie wicz (2008), meneliti tentang pengaruh interaktif antara personal spirituality dan organizational spirituality worker consequences. Hasilnya menunjukkan adanya pengaruh signifikan antara organizational spirituality dengan job involvement, organizational identification, organizational frustration, dan work reward satisfaction. Hasil lain menunjukkan bahwa interaksi antara nilai-nilai personal spirituality dan nilai-nilai organizational spirituality memiliki bukti pengaruh kecil terhadap worker consequences. Selain itu juga bahwa organizational spirituality gagal memprediksi extrinsic reward satisfaction. Pengaruh workforce spirituality pada dimensi alignment of value juga memiliki dampak yang tidak signifikan terhadap work attitudes, khususnya pada indikator intrinsic work satisfaction, job involvement, dan organization based self esteem (Milliman, et al. 2003).

Merujuk pada beberapa hasil penelitian terdahulu, khususnya hasil penelitian (Gupta et.al, 2014) yang menyarankan perlunya dimasukkan variabel intervening dalam hubungan antara workplace spirituality dan job performance. Pengaruh workforce spirituality terhadap employee work attitude tidak sepenuhnya memiliki dampak signifikan, khususnya pada indikator intrinsic work satisfaction, job involvement, dan organization based self esteem (Milliman et al., 2003), maka untuk mengisi kesenjangan hubungan antara workforce spirituality dengan job satisfaction, studi kali ini akan dikembangkan dengan memasukkan variabel intervening Islamic work ethics. Studi ini sangat disarankan mengingat obyek kajian adalah para professional yang terdiri dari staff pengajar dan manajer perusahaan yang menganut relegiusitas Islam. Islam meyakini bahwa kebahagiaan seseorang sangat dipengaruhi oleh sistem sosial ekonomi. Konsern utama dari sistem kebahagiaan Islam merupakan sebuah model masyarakat yang menjamin keadilan sosial, perlindungan hak-hak masyarakat, dengan mengutamakan pada persamaan hak, keadilan dan ihsan (Arshad, 2011). 


\section{B. TELAAH PUSTAKA}

\section{Workplace Spirituality}

Dalam penelitian ini akan mengkaji makna dan implikasi spirituality dalam konteks workplace. Terdapat beberapa definisi workplace spirituality. Sebagai contoh spirituality didefinisikan sebagai kesadaran kita dari dalam (Gulliory, 2000), sebuah bentuk tertentu dari perasaan kerja yang mendorong untuk bertindak (Dehler and Welsh, 1994). Workplace spirituality melibatkan usaha untuk menemukan tujuan hidup yang utama dari seseorang, untuk mengembangkan hubungan yang kuat dengan sesama karyawan dan orang lain hubungannya dengan pekerjaan, dan menjaga konsistensi dengan keyakinan seseorang dan nilai-nilai organisasi (Mitroff, Denton, \& Alpaslan, 2009). Workplace spirituality didefinisikan sebagai pengakuan bahwa karyawan memiliki kehidupan dari dalam yang terpelihara oleh tempat kerja yang mendukung, sehingga mendapatkan menjadi sebuah komunitas (Ashmos \& Duchon, 2000). Dalam kenyataannya, secara historis pemahaman spiritualitas berakar dari agama. Namun dalam perkembangannya, spirituality di tempat kerja saat ini tidak hanya melibatkan pada tradisi agama tertentu, tetapi lebih didasarkan pada nilai-nilai personal dan filosofi (Mitroff et al., 2009).

Workplace spirituality diukur dengan menggunakan tiga dimensi, yakni meaningful work (level individu), sense of community (level kelompok), dan alignment work organizational values (level organisasi) (Milliman et al., 2003). Meaningful work memiliki tiga indikator, yaitu: enjoy work, energized by work, dan work gives personal meaning and purpose. Sense of community memiliki tiga indikator, yakni: sense of connection with co-workers, employees support each other, dan linked with a common purpose. Sementara itu alignment work organization values memiliki tiga indikator, yakni: feel connected to organization's goal, identify with organization's mission and values, dan organization cares about employees.

Dimensi lain dari workplace spirituality meliputi employee well-being, sense of meaning and purpose, and sense of community dan interconnectedness (Karakas, 2010). Dimensi employee well-being memiliki indikator; increasing morale, increasing commitment and productivity, reducing stress, burnout dan workaholism. Sementara dimensi sense of meaning purpose memiliki indikator perform better, more productive, creative at work. Dimensi ketiga sense of community and interconnectedness memiliki indikator; interpersonal relationship, collective dimensions, dan social dynamics of spirituality. Sementara itu (Gupta et.al, 2014), mengemukakan bahwa workplace spirituality memiliki empat dimensi, yaitu: meaning work, sense of community, organization values, dan compassion. 
Sebuah model komprehensif telah dikembangkan untuk memfasilitasi workplace spirituality. Terdapat empat dimensi dalam workplace spirituality (Pawar B.S., 2009). Dimensi pertama individual-focused views yang lebih memfokuskan pada aspek hubungan individu dan mengusulkan bahwa pengembangan spiritual dalam individu karyawan merupakan hasil dari fasilitas workforce spirituality dengan mempromosikan karyawan pengalamannya di tempat kerja. Dimensi kedua, the group-focus view yang mana kelompok dapat berkembang dalam sebuah komunitas sebagai makna dari pengalaman spiritual dan hal ini dapat meningkatkan workplace. Dimensi ketiga, organization-focused views yang terfokus pada aspek organisasional seperti nilai-nilai dan budaya untuk untuk memfasilitasi workplace spirituality. Terakhir, the leadership-focused view yang menguraikan sebuah mekanisme untuk mempertajam aspek visi dan budaya organisasi untuk memfasilitasi pengalaman spiritual karyawan di tempat kerja.

\section{Islamic Work Ethics (IWE)}

Etika kerja Islam dapat didefinisikan sebagai seperangkat prinsip moral yang membedakan benar dan salah (Beekun, 1997) dalam konteks Islam. IWE didasarkan pada AlQuran, karena Al-Qur'an adalah penjaga perilaku Muslim di semua bidang kehidupan. IWE menekankan kerja sama dalam pekerjaan, dan konsultasi dipandang sebagai cara untuk mengatasi hambatan dan menghindari kesalahan. Itu juga menekankan kerja kreatif sebagai sumber kebahagiaan dan prestasi. Kerja keras dipandang sebagai kebajikan dan mereka yang bekerja keras dianggap lebih mungkin berhasil dalam hidup.

IWE dan etika kerja Protestan sangat menekankan pada kerja keras, komitmen, dan dedikasi untuk bekerja, kreativitas kerja, menghindari metode akumulasi kekayaan yang tidak etis, kerja sama, dan daya saing di tempat kerja. (Yousef, 2000). Studi tentang dampak of IWE dan perceived organizational justice terhadap turnover intentions, job satisfaction, dan job involvement, hasilnya menunjukkan bahwa IWE memiliki hubungan positif dengan kepuasan dan keterlibatan. Namun, IWE memiliki dampak negatif terhadap turnover intention. Distributive fairness memiliki dampak negative terhadap turnover intention, sementara itu procedural justice memiliki dampak positif terhadap kepuasan kerja (Khan, Abbas, Gul, \& Raja, 2013).

Bersama-sama, kontroversi dalam hubungan antara jenis keadilan dan hasil, seperti yang dibahas sebelumnya, menunjukkan kemungkinan adanya faktor pribadi atau kontekstual yang dapat memoderasi hubungan ini (Colquitt et al. 2006). Karena IWE menekankan keadilan dan kedermawanan di tempat kerja (Yousef, 2000a), ia mungkin merupakan moderator penting 
dalam hubungan antara jenis keadilan dan hasil pekerjaan. IWE adalah bagian dari sistem kepercayaan individu, oleh karena itu kami berpendapat bahwa individu-individu yang tinggi di IWE, akan dapat melindungi terhadap tidak adanya keadilan organisasi. Khususnya, situasi di mana ada kurangnya keadilan distributif dan prosedural mungkin kurang berbahaya bagi individu yang tinggi pada IWE. Hal ini dikarenakan individu-individu ini mungkin tidak terlalu peduli tentang tidak adanya keadilan distributif dan prosedural. Ketika seorang karyawan merasakan ketidakadilan dalam prosedur dan distribusi imbalan, persepsi keadilan yang lebih rendah ini cenderung mengurangi kepuasan kerja dan meningkatkan niat seseorang untuk menarik diri dari pekerjaan. Namun, individu dengan IWE tinggi harus lebih kecil kemungkinannya merespons negatif terhadap perawatan yang tidak adil ini.

Menurut IWE, tujuan yang terkait dengan pekerjaan dianggap sebagai kewajiban moral yang harus dicapai bahkan tanpa adanya prosedur yang adil dan distribusi hadiah. Sebagai contoh, Al-Quran mengatakan "dan dia yang melakukan amal saleh dan dia adalah seorang mukmin, dia tidak akan memiliki rasa takut akan ketidakadilan atau kekurangan" (20: 112). Oleh karena itu, kami percaya bahwa individu, yang tinggi di IWE, mungkin tidak repot ketika keadilan organisasi rendah. Bouma dan rekannya menyatakan bahwa tekanan pada aktivitas dan hubungannya dengan akhirat dipahami berarti bahwa umat Islam memiliki kewajiban moral untuk bekerja (Bouma 2003; Bouma et al. 2003).

Penelitian tentang religiusitas menunjukkan bahwa agama menggerakkan sistem kepercayaan integral dari seorang individu dan itu secara signifikan mempengaruhi nilai-nilai kerja intrinsik dan ekstrinsik individu tersebut (Parboteeah et al. 2009). IWE adalah komponen penting dari kepercayaan Muslim dan sistem nilai, karyawan dengan tingkat IWE yang lebih tinggi akan menunjukkan tingkat kepuasan kerja dan keterlibatan kerja yang lebih tinggi dan niat turnover yang rendah bahkan dalam situasi di mana persepsi keadilan prosedural dan distributif rendah (Khan et al., 2013).

Studi ini mengusulkan untuk menyelidiki pengaruh etos kerja Islami pada persepsi keadilan di antara karyawan di lembaga keuangan mikro syariah di Indonesia. Konstruk keadilan organisasi mencakup tiga dimensi, yaitu keadilan distributif, prosedural, dan interaksional. Sampel terdiri dari 370 karyawan dari 60 lembaga keuangan mikro syariah di Jawa Tengah, Indonesia. Hasil penelitian menunjukkan bahwa etos kerja Islam berkontribusi positif terhadap tiga dimensi persepsi keadilan yang disebutkan di atas. Implikasi, keterbatasan, dan saran untuk penelitian masa depan dibahas (Rokhman \& Hassan, 2012). 


\section{Organizational Citizenship Behavior (OCB)}

OCB yang dipelajari di bawah konteks perilaku organisasi, dapat ditelusuri kembali ke tahun 1930-an dan muncul sebagai gagasan independen pada 1980-an (Karaaslan, Özler, \& Kulaklıoglu, 2009). OCB adalah seperangkat perilaku efektif yang tidak secara eksplisit ditulis di bagian deskripsi pekerjaan atau bisnis, tetapi dapat meningkatkan kinerja bisnis. Organ (1988), mendefinisikan OCB sebagai perilaku individu yang bersifat diskresi, tidak secara langsung atau eksplisit diakui oleh sistem penghargaan formal, dan bahwa secara agregat mempromosikan fungsi organisasi yang efektif.

OCB berarti bahwa orang akan dimasukkan ke dalam upaya ekstra yang dilakukan dengan senang hati yang melampaui persyaratan dasar pekerjaan dan tidak dipaksa oleh aturan tertulis apa pun (Atalay, 2005). Pada kenyataannya, perusahaan-perusahaan di mana hanya aturan tertulis dan pemaksaan eksplisit digunakan pada dasarnya lemah dan tidak diharapkan bertahan lama selama masa-masa inovatif dan dinamis (Wyss, 2006). Untuk menjadi sukses di dunia yang kompetitif saat ini, OCB membantu organisasi atau perusahaan mempercepat menuju inovasi dan langkah-langkah produktif. Pihak berwenang tidak dapat memaksakan perilaku ini karena mereka dihasilkan dari preferensi keinginan orang sendiri dan termasuk perilaku yang berkontribusi lebih pada efektivitas organisasi (Organ, 1997). Selain fakta bahwa OCB mencakup kesediaan, preferensi pribadi, dan upaya tersirat, literatur terkait telah membuat poin penting tentang OCB sepanjang tahun (Karaaslan et al., 2009):

- OCB tidak dalam hubungan langsung dengan sistem hukuman dan penghargaan dan tidak berkembang dengan cara ini.

- Perilaku ini tertanam dalam kegiatan organisasi dan hanya terkait dengan fungsi dan efektivitas organisasi.

- OCB tidak ditulis dalam definisi pekerjaan apa pun dan hasil terjadi dari upaya ekstra pribadi seseorang.

- Perilaku ini tidak hanya berkontribusi pada organisasi tetapi juga bagi pelaku, dirinya sendiri.

Ada banyak dimensi yang terhubung ke OCB. Setelah penelitian literatur yang luas, ditemukan bahwa 30 perilaku kewarganegaraan yang berbeda telah ditentukan dan struktur multidimensi OCB telah diperiksa (Podsakoff, 2000). Namun taksonomi yang paling dikenal ditetapkan oleh Organ (1997) yang mendaftarkan OCB di bawah lima kelompok: altruisme, hati nurani, olahraga, kesopanan, dan kesopanan sipil. Altruisme adalah semua perilaku sukarela, khusus ditujukan untuk membantu orang lain dalam masalah yang relevan secara 
organisasi atau dalam kaitannya dengan masalah dalam organisasi (Kamer, 2001). Membantu seorang kolega yang memiliki beban kerja besar dengan bekerja lembur dengannya atau memberikan informasi yang relevan bagi pendatang baru adalah contoh bagus dari altruisme. Mereka tidak suka atau tidak setuju dengan perubahan yang terjadi dalam organisasi. Contoh dari dimensi OCB adalah menghindari kepicikan seperti gosip, dan tidak mengeluh tentang halhal sepele.

Sopan santun adalah perilaku diskresioner yang mencegah masalah terkait pekerjaan dengan karyawan lain. Memberitahu pihak lain sebelum keputusan yang mungkin mempengaruhi mereka terhubung dengan sopan santun (Deluga, 1995). Sopan santun mencakup perilaku konstruktif terhadap orang lain dan mendapatkan pendapat orang lain jika mereka mungkin terpengaruh. Ini mencakup bersikap sopan dan mempertimbangkan orang lain untuk mencegah konflik.

Kebajikan sipil didefinisikan sebagai berpartisipasi secara bertanggung jawab dan memiliki kepedulian terhadap suatu organisasi (Çınar, 2000). Ini ditandai dengan perilaku yang menunjukkan kekhawatiran mendalam karyawan dan minat aktif dalam kehidupan organisasi (Y. S. Chen, 2008). Orang-orang dengan kebajikan sipil dalam suatu organisasi diharapkan bertanggung jawab dan aktif, mengambil bagian dalam semua proses praktis dan politis untuk kepentingan semua, sementara juga memantau kemungkinan ancaman yang dapat membahayakan kesejahteraan organisasi.

Hati nurani merupakan kesadaran berhubungan dengan perilaku diskresi yang membantu organisasi secara umum dan melampaui persyaratan peran minimum organisasi (Organ, 1990). Conscientiousness mencakup perilaku yang mencerminkan penerimaan yang tulus dan kepatuhan terhadap peraturan, peraturan, dan prosedur di tempat kerja dengan cara di atas apa yang diharapkan (Podsakoff et al., 2000).

Sikap sportif berarti toleran dalam kondisi yang kurang ideal dan menghindari mengeluh dan meledakkan masalah di luar proporsi. Perilaku yang termasuk dalam dimensi sportivitas adalah toleransi, rasa hormat, dan penghindaran dari masalah omong kosong / pembicaraan (Altınbaş, 2008).

Hasil penelitian spiritualitas tempat kerja dengan kepuasan kerja menunjukkan hasil-hasil yang berbeda. (Gupta M et al, 2014), menyatakan ada pengaruh workplace spirituality, khususnya sense of community dan organizational value terhadap kepuasan kerja. (Milliman et al., 2003), secara umum terdapat pengaruh positif dan signifikan antara Workplace spirituality dengan variabel hasil. Dimensi meaningful work tidak memiliki pengaruh signifikan terhadap 
intention to quit. Demikian juga variabel alignment of values tidak berpengaruh signifikan terhadap intrinsic work satisfaction, job involvement, dan OCB.

\section{Hubungan antara Workplace Spirituality and OCB}

Berbagai dimensi workplace spirituality telah dikemukakan oleh peneliti-peneliti terdahulu. Dalam konteks penelitian ini workplace spirituality akan mengacu pada berbagai dimensi antara lain: meaningfullwork, sense of community, organization value, dan compassion (Gupta M. et al, 2014). Hasil penelitiannya menunjukkan bahwa workplace spirituality memiliki pengaruh yang signifikan terhadap kepuasan kerja. Namun demikian, untuk dimensi meaningfull work dan compassion pengaruhnya tidak signifikan. Penelitian lain menunjukkan hasil bahwa workplace spirituality dimensions memiliki pengaruh signifikan terhadap berbagai dimensi outcome variabel, seperti: $\mathrm{OCB}$, organizational commitment, intention to quit, intrinsic work satisfaction, job involvement, dan organization based self esteem (Milliman et al., 2003).

Workplace spirituality pada dimensi alignment of values pengaruhnya sangat kecil terhadap intrinsic work satisfaction, job involvement, dan organization based self esteem. Namun, secara umum seluruh variabel yang diobservasi memiliki hubungan signifikan dengan yang lain, dan spiritual leadership dapat memprediksi keseluruhan empat dimensi dari OCB, khususnya civic virtue. Hal ini dapat dipahami bahwa spiritual leadership memiliki kontribusi yang kuat dalam pembentukan OCB untuk diserap dalam organisasi (Kaya, 2015). Hasil lain menunjukkan bahwa terdapat hubungan antara religiosity terhadap stres dan burnout, kepuasan kerja, komitmen organisasi, OCB (Kutcher, Bragger, Rodriguez-srednicki, \& Masco, 2010). H1 : semakin meningkat workplace spirituality akan semakin meningkatkan OCB

\section{Hubungan antara workplace spirituality dengan Islamic Work Ethics}

Karakteristik umum dari semua aliran filsafat Islam adalah bahwa kesejahteraan dan kesejahteraan terkait dengan kebahagiaan (Arabi, 2016). Menurut filsafat Islam ada beberapa perbedaan antara kesejahteraan dan kebahagiaan. Kesejahteraan dan kesejahteraan muncul dari aspek-aspek situasi dan peristiwa duniawi ini, yang menjadikannya menyenangkan dan menyenangkan bagi seseorang, sementara kebahagiaan tidak selalu bertepatan dengan pengalaman yang menyenangkan. Secara umum, kebahagiaan meresapi seluruh kehidupan seseorang dan aspek seseorang sementara kesejahteraan mungkin hanya berkaitan dengan periode kehidupan seseorang dan beberapa aspeknya.

Pandangan Islam kehidupan seseorang berlanjut di dunia lain, sehingga konsep kebahagiaan memiliki cakupan eksistensial yang lebih besar daripada kesejahteraan. Selain itu, pengakuan dan spesifikasi barang yang membuat seseorang bahagia dan sangat membutuhkan 
pengetahuan di sana tentang kepentingan terbaiknya (selama masa hidupnya) dan tentang kebaikan nyata baginya dan manusia pada umumnya. Oleh karena itu, dalam pendekatan Islam, seseorang dengan baik dikaitkan dengan kesempurnaannya dan dengan berkembangnya sejarah dalam cahaya kecerdasan murni yang tidak menjadi budak naluri binatang. Oleh karena itu, jika seseorang mencapai kesempurnaan dia akan berada dalam keadaan kesejahteraan (Arabi, 2016).

Workplace spirituality pada tataran individu akan meningkatakan employee well-being and quality of life. Peningkatan kebahagiaan karyawan secara umum dapat terjadi melalui peningkatran moral karyawan, peningkatan komitment, dan peningkatan produktivitas. Pada sisi lain juga dapat mengurangi stres, kejenuhan, dan workaholic (Karakas, 2010). Kebahagiaan dalam konteks Islam dalam penelitian ini akan difokuskan pada tiga indikator, yaitu: kebahagiaan individu, kebahagiaan keluarga, dan kebahagiaan organisasi. Workplace spirituality dalam perspektif sumber daya manusia juga dapat meningkatkan kebahagiaan karyawan, meningkatkan produktivitas karyawan. Hasil penelitian menunjukkan bahwa terdapat positif dan korelasi yang signifikan antara personal well-being dan religiosity. Wellbeing juga menunjukkan korelasi positif signifikan terhadap beliefs, worship dan prayer (Achour, et al,. 2015)

$\mathrm{H} 2$ : Semakin meningkatnya workplace spirituality akan meningkatkan Islamic work ethics

\section{Hubungan antara Islamic Work Ethics dengan OCB}

Konsern utama dari sistem kebahagiaan Islam merupakan sebuah model masyarakat yang menjamin keadilan sosial, perlindungan hak-hak masyarakat, dengan mengutamakan pada persamaan hak, keadilan dan ihsan (Arshad, 2011). Sistem religiusitas dan sosial dalam Islam akan membentuk kebahagiaan individu, keluarga, dan masyarakat. Islam akan menjamin kesejahteraan manusia dengan memenuhi kebutuhan-kebutuhan hidup melalui sistem keamanan sosial secara komprehensif dan menjamin keadilan sosial. Kebahagiaan karyawan memiliki pengaruh positif dan signifikan terhadap peningkatan produktivitas dan kinerja karyawan (Karakas, 2010). Hubungan sosial akan sangat membantu dalam memperbaiki prospek karir.

Temuan lain juga mengindikasikan bahwa pertemuan dengan teman kerja dapat meningkatkan kepuasan kerja melalui peningkatan kepercayaan dan peningkatan jaringan (Fiorillo \& Nappo, 2014). Yousef (2000), dalam penelitiannya menyimpulkan adanya pengaruh antara IWE dengan tendensi afektif dan perilaku dengan komitmen sebagai variabel mediating. Dengan kata lain bahwa komitmen continue dan komitmen normatif memediasi pengaruh 
antara IWE terhadap dimensi kognitif. IWE juga memiliki pengaruh positif terhadap persepsi keadilan (Rokhman \& Hassan, 2012).

Studi untuk menguji hubungan tidak langsung antara Leader-Member Exchange (LMX) dan $O C B$ follower melalui Organizational Identification (OI) sebagai variabel intervening dengan menggunakan Social Identity Theory (STI), dan hasilnya menunjukkan bahwa hubungan antara LMX dan perilaku citizenship dimediasi oleh OI semakin meningkat setelah dimoderasi oleh Islamic Work Ethics (IWE). Hasilnya mendukung peran mediating dari organizational identification (OI) dalam hubungan antara LMX dan follower citizenship behavior.

H3 : Semakin meningkatnya Islamic Work Ethics akan meningkatkan OCB

Gambar 1. Model Penelitian

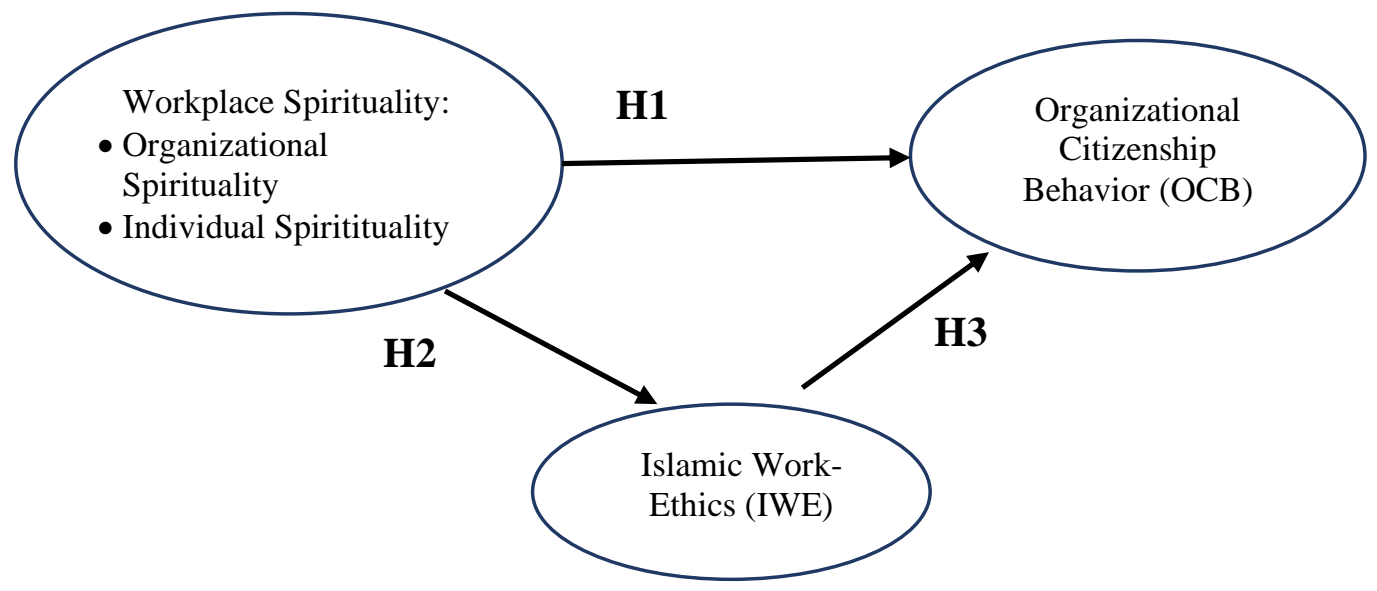

\section{METODOLOGI PENELITIAN}

\section{Variabel Penelitian dan Pengukuran}

Studi ini akan melibatkan tiga konstruk atau latent variabel, yaitu spirituality sebagai independen variabel, organizational citizenship behavior (OCB) sebagai dependen variabel, dan Islamic Work Ethics sebagai intervening variabel. Spirituality memiliki dua dimensi, yaitu organizational spirituality dan individual spirituality. Organizational spirituality diukur dengan lima indikator, individual spirituality diukur menggunakan lima indikator.

Sementara itu OCB diukur menggunakan lima indikator, dan variabel Islamic Work Ethics menggunakan lima indikator. Pengukuran indikator organizational spirituality menggunakan organizational spiritual value scale (OSVS) dari (Walt, 2007), 1=complete false sampai dengan 5=complete true. Variabel individual spirituality diukur menggunakan Individual Spirituality Scale: The daily spirituality experience scale (DSES); (Underwood, 2011), dengan kriteria: Every day (5), Most day (4), Same day (3), Once in a while (2), dan 
Never (1). Variabel Islamic work ethics menggunakan likert scale 5 point (Arshad, 2011), $1=$ strongly disagree sampai 5=strongly agree. Sementara itu OCB diukur menggunakan likert scale 5 point (C. Y. Chen \& Yang, 2012), 1=strongly disagree sampai 5=strongly agree.

\section{Populasi dan Responden}

Studi ini melibatkan para profesional sebagai responden di wilayah Provinsi Jawa Tengah yang berjumlah 200 profesional. Jumlah populasi penelitian tidak diketahui dengan pasti, sehingga teknik sampling yang digunakan adalah purposive sampling. Purposive sampling difokuskan pada responden profesional yang terdiri dari staf pengajar dan manajer perusahaan. Mereka terdiri dari staf pengajar dan manajer perusahaan.

Data diperoleh dari responden dengan menggunakan instrument kuesioner yang menanyakan tentang spirituality, OCB, dan Islamic Work Ethics. Instrumen kuesioner didistribusikan kepada responden dengan menggunakan google form, dengan alasan letak geografis responden sangat berjauhan, sehingga dengan metode google form akan sangat membantu dan mempercepat tanggapan dari responden penelitian.

\section{Analisis Data}

Pada tahapan pertama akan diuji kualitas instrument penelitian, yaitu dengan uji validitas dan reliabilitas. Uji validitas dengan mengkorelasikan antara indikator dengan total indikator. Adapun kriteria sebuah indikator valid adalah jika nilai signifikansinya $<=0,05$. Sementara itu uji reliabilitas dilakukan dengan menggunakan koefisien Cronbach alpha. Kriteria sebuah varibel dikatakan reliable apabila nilai Cronbach alpha-nya di atas 0,7. Tahapan berikutnya adalah dilakukan uji regresi dengan tahapan sebagai berikut:

- $\quad$ Uji regresi pertama, dengan persamaan JS=a+b1WS

- $\quad$ Uji regresi kedua, dengan persamaan JS=a+b1WS + b2 IWB

\section{HASIL DAN PEMBAHASAN}

Pengumpulan data responden dilakukan dengan menggunakan kuesioner dan didistribusikan dengan Google-form. Jumlah responden yang berpartisipasi dalam studi ini sebanyak 200 orang, yang terdiri dari para professional, yang meliputi dosen sebanyak 68\%, dan manajer perusahaan sebanyak 28\%. Dari hasil jawaban responden menunjukkan bahwa rata-rata usia responden adalah 45,85 tahun, dengan responden termuda berusia 27 tahun, dan responden tertua berusia 59 tahun. Sementara itu dari masa kerja, rata-rata responden sudah bekerja selama 18,76 tahun. 
Tabel 1. Nilai mean dan standar deviasi indikator

\begin{tabular}{|c|c|c}
\hline Indikator & Mean & Std. Deviation \\
\hline Usia & 45.8450 & 8.28093 \\
\hline Masker & 18.7600 & 8.39911 \\
\hline os1 & 4.0300 & .72922 \\
\hline os2 & 3.8950 & .67547 \\
\hline os3 & 4.1550 & .67323 \\
\hline Os & 12.0800 & 1.81938 \\
\hline is1 & 4.9150 & .27958 \\
\hline is2 & 4.9150 & .27958 \\
\hline is3 & 4.8100 & .39329 \\
\hline is4 & 4.7550 & .43117 \\
\hline is5 & 4.5850 & .57831 \\
\hline Is & 23.9800 & 1.45264 \\
\hline iwe1 & 4.3000 & .54910 \\
\hline iwe2 & 4.2000 & .62607 \\
\hline iwe3 & 4.2750 & .68683 \\
\hline iwe4 & 4.2250 & .58831 \\
\hline iwe5 & 4.2750 & .68683 \\
\hline Iwe & 21.2750 & 2.53605 \\
\hline ocb1 & 4.2500 & .43410 \\
\hline ocb2 & 4.1200 & .68406 \\
\hline ocb3 & 3.9150 & .78796 \\
\hline ocb4 & 4.1050 & .60482 \\
\hline ocb5 & 4.1400 & .54024 \\
\hline Ocb & 20.5300 & 2.11696 \\
\hline
\end{tabular}

Sumber: Data primer diolah (2019)

\section{Uji kualitas kuesioner}

Uji kualitas kuesioner dimaksudkan untuk menjamin bahwa instrumen penelitian memiliki validiatas yang baik. Selain itu juga instrumen penelitian memiliki reliabilitas atau kehandalan. Adapun uji validitas dilakukan dengan mengkorelasikan antara indikator dengan total indikatornya, dan sebuah indikator dikatakan valid apabila memiliki nilai signifikansi dibawah 0,05. Dari hasil product moment correlation antara indikator masing-masing variabel dan total indikator, hasilnya menunujukkan bahwa semua nilai signifikannya adalah 0,000. Hasil ini mengindikasikan bahwa semua indikator yang digunakan dalam penelitian ini disimpulkan valid.

Sementara itu uji reliabilitas dilakukan untuk menilai kehandalan sebuah variabel. Ujinya dilakukan dengan menggunakan Cronbach alpha dengan bantuan SPSS. Hasil uji reliabilitas menunjukkan nilai reliabilitas Organizational spirituality dengan tiga indikator memiliki Cronbach $\alpha=0,847$, individual spirituality dengan lima indikator memiliki Cronbach $\alpha=0,758$, organizational citizenship behavior dengan lima indikator memiliki Cronbach $\alpha=0,865$, dan 
Islamic Work Ethics dengan lima indikator memiliki Cronbach $\alpha=0,710$. Nilai Cronbach alpha dikatakan reliabel apabila nilainya $>0,07$.

Analisis regresi dalam studi ini digunakan untuk mengetahui pengaruh independen variabel terhadap dependen variabel. Variabel independen spirituality menggunakan dua dimensi, yaitu organizational spirituality dan individual spirituality. Sementara itu dependen variabelnya adalah OCB, dan variabel intervening adalah Islamic Work Ethics. Model pertama menguji pengaruh antara organizational spirituality dan individual spirituality terhadap Islamic Work Ethics. Hasil studi menunjukkan bahwa organizational spirituality memiliki pengaruh positif signifikan terhadap Islamic Work Ethics (beta=0,772, dan signifikansi=0,000). Temuan ini menunjukkan bahwa semakin meningkatnya organizational spirituality maka akan meningkatkan Islamic Work Ethics, dan pengaruhnya sangat signifikan. Sementara itu dimensi individual spirituality tidak memiliki pengaruh terhadap Islamic Work Ethics.

Hasil model 2 menunjukkan bahwa organizational spirituality memiliki pengaruh signifikan terhadap OCB (beta=0,411 dan sign. 0,000), dan Islamic Work Ethics juga memiliki pengaruh signifikan terhadap OCB (beta=0,381 dan sign. 0,000). Konsisten dengan model 1, untuk variabel individual spirituality tidak memiliki pengaruh terhadap OCB. Nilai $\mathrm{R}^{2}$ pengaruh organizational spirituality dan individual spirituality terhadap Islamic work ethics sebesar 0,580. Sementara itu nilai $\mathrm{R}^{2}$ pengaruh antara organizational spirituality, individual spirituality, dan Islamic Work Ethics terhadap OCB sebesar 0,548.

Tabel 2. Hasil Analisis Regresi

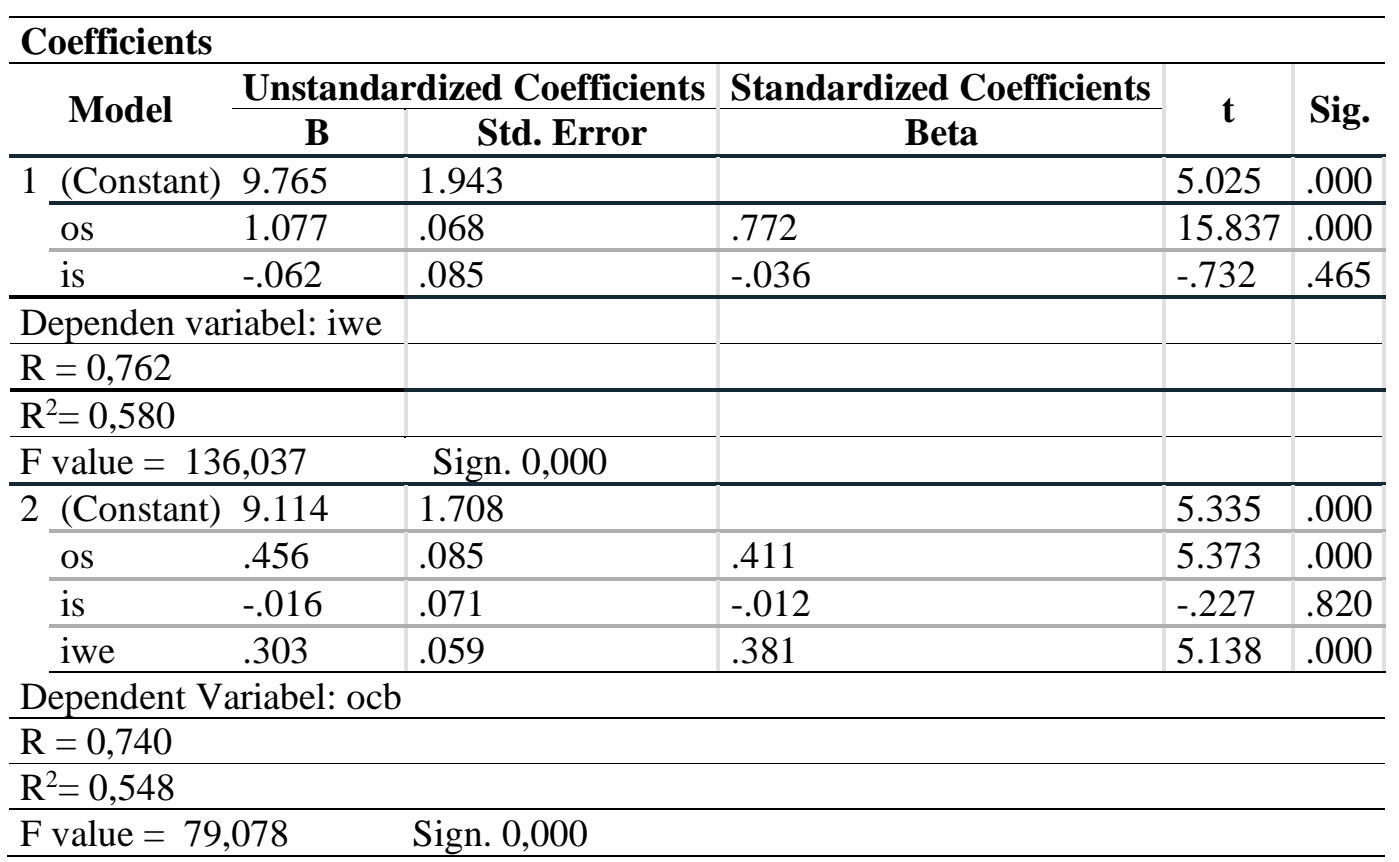

Sumber: Data primer diolah (2019) 
Hasil studi menunjukkan bahwa variabel organizational spirituality memiliki hubugan signifikan terhadap OCB dan Islamic Work Ethics. Selain itu juga variabel Islamic Work Ethics memiliki hubungan signifikan terhadap OCB. Namun demikian, individual spirituality tidak memiliki hubungan signifikan dengan OCB maupun Islamic Work Ethics. Temuan ini menunjukkan bahwa organizational spirituality yang dicirikan dengan keterlibatan dalam kegiatan-kegiatan relegius, keterlibatan dalam kegiatan religius yang lain, dan menikmati berbagai aktivitas religius yang semakin tinggi akan meningkatkan para professional untuk lebih mementingkan orang lain, menuruti kata hati, lebih sportif, memiliki sikap sopan dan hormat, serta mengutamakan kepentingan umum.

Hasil lain juga mengindikasikan bahwa organizational spirituality yang tinggi dapat meningkatkan kerjasama dalam bekerja, kesediaan konsultasi dalam pekerjaan, kerja lebih kreatif, kerja keras, dan memiliki komitmen kerja yang lebih tinggi. Hasil studi ini menunjukkan bahwa Islamic Work Ethics merupakan variabel penting dalam upaya-upaya untuk meningkatkan OCB melalui pendekatan organizational spiritual.

Temuan ini sejalan dengan (Kolodinsky et al., 2008), yang menyatakan bahwa organizational spirituality dinyatakan berhubungan secara positif dengan job involvement, organizational identification, dan work rewards satisfaction serta berhubungan secara negatif dengan organizational frustration. Personal spirituality berhubungan secara positif intrinsic, extrinsic, and total work rewards satisfaction. Hasil studi memberikan dukungan terhadap pengaruh langsung dari spirituality, khususnya organizational spirituality terhadap Islamic Work Ethics dan organizational citizenship behavior.

Disisi lain, variabel individual spirituality memiliki pengaruh tidak signifikan terhadap IWE maupun OCB. Hasil temuan bertolak belakang, dimana dalam pengaruh langsung individual spirituality pemimpin memiliki pengaruh signifikan terhadap perilaku spiritual pemimpin kepada anggotanya, sementara itu organizational spirituality tidak memiliki pengaruh signifikan (Pawar, 2014). Penggabungan antara nilai-nilai spiritual dan perilaku spiritual dapat mempengaruhi perilaku spiritual pemimpin kepada anggotanya.

Jurkiewicz and Giacalone (2004) telah memfokuskan pada aspek organizational value dalam membangun konsep spiritualitas di tempat kerja. Giacalone and Jurkiewicz (2003) mendefiniskan workplace spirituality sebagai sebuah kerangka nilai-nilai organisasional yang dibuktikan dalam budaya yang dapat mempromosikan karyawan yang berkualitas melalui proses kerja, fasilitasi kerjasama dengan karyawan lain dengan cara-cara yang menyenangkan. Berdasarkan pada diskusi sebelumnya, dalam studi ini spiritual organization didefinisikan 
sebagai hadirnya nilai-nilai spiritual dalam fungsi organisasi (Milliman et al. 1999). Selanjutnya dalam Southwest Airlines telah diadopsi nilai-nilai spiritual dalam budaya mereka, dan mampu mempengaruhi perilaku karyawan.

Dalam kajian nilai-nilai spiritual berbasis model manajemen, nilai-nilai spiritual dari organisasi dapat mempengaruhi misi, sasaran dan tujuan organisasi. Lebih lanjut Fry (2003), menekankan bahwa dengan berpartisipasi dalam tim yang memiliki budaya altruistic live, maka para pengikut akan mulai mengembangkan, memperbaiki, dan mempraktekkan kepemimpinan personalnya sendiri yang nantinya akan juga mewujudkan visinya, sehingga kehidupanya akan lebih akan lebih bermakna, menciptakan perbedaan, dan menggabungkan nilai-nilai dan sikap altruistic love dalam interaksi sosial dengan yang lain untuk menyelesaikan pekerjaan bersamasama.

Fry \& Cohen, (2009) menyampaikan bahwa beberapa nilai dalam altruistic love menggambarkan kerendahan hati, kesabaran, sifat memaafkan dan kebaikan-kebaikan yang sesuai dengan nilai-nilai spiritual (Pawar, 2014). Hubungan antara perilaku spiritual pemimpin dan bawahan diantara nilai-nilai organisasi dan pentingnya outcome kerja, bagaimana karyawan memandang organisasional spirituality berdampak pada sikap, keyakinan, kepuasan, dan kapasitas personal untuk mengantisipasi tantangan pekerjaan. Pandangan ini juga dapat mengesankan hal yang masuk akal bahwa persepsi karyawan terhadap nilai-nilai spiritual organisasi bisa untuk memperkenalkan perilaku spiritual pada karyawan. Berdasarkan pada pandangan ini, terkesan ada hubungan antara nilai-nilai spiritual organisasi dan berilaku karyawan dalam organisasi (Kolodinsky et al., 2008).

Islamic Work Ethics memiliki pengaruh signifikan terhadap OCB. Artinya bahwa semakin meningkatnya kerjasama dalam bekerja antar karyawan, adanya konsultasi dalam pekerjaan, kerja legih kreatif yang didukung dengan kerja keras, dan dilandasi dengan komitmen tinggi akan mampu meningkatkan OCB dalam bentuk bahwa para professional akan lebih mementingkan orang lain, selalu menuruti kata hati, lebih sportif dalam bekerja, memiliki sikap kesopanan dan rasa hormat, dan lebih mementingkan kepetingan umum. IWE memiliki hubungan positif terhadap kepuasan dan keterlibatan karyawan, tetapi memiliki hubungan negatif terhadap minat untuk berpindah (Khan et al., 2013).

IWE didefinisikan sebagai kesatuan prinsip-prinsip moral yang antara yang benar dan salah dalam konteks Islam (Beekun, 1997). IWE berdasarkan pada Qur'an, sebab Qur'an merupakan petunjuk bagi perilaku umat Islam dalam seluruh aspek kehidupan. Kegiatan IWE mengutamakan kerjasama dalam bekerja, dan konsultasi dipandang sebagai cara yang 
menciptakan keajaiban dan mengurangi kesalahan. Selain itu juga menekankan kerja kreatif sebagai sumber kebahagiaan dan prestasi. Kerja keras dipandang sebagai sesuatu yang nyata sehingga seseorang yang bekerja keras akan sangat mungkin untuk sukses dalam hidupnya. Islamic work ethics dan protestant work ethics mempertimbangkan keutamaan pada kerja keras, komitmen, dedikasi dalam bekerja, kerja kreatif, menghindarkan metode mencapai kesejahteraan, kerjasama dan persaingan di tempat kerja yang tidak beretika (Yousef, 2000).

\section{E. KESIMPULAN}

Berdasarkan pada hasil kajian yang telah dipaparkan, maka dapat disimpulkan bahwa variabel Islamic Work Ethics merupakan variabel penting dalam hubungan antara spirituality (organizational spirituality dan individual spirituality) dengan OCB. Artinya bahwa untuk meningkatkan OCB akan difokuskan pada peningkatan peran dari spirituality khususnya organizational spirituality. Sementara itu individual spirituality tidak memiliki pengaruh signifikan terhadap Islamic Work Ethics maupun organizational citizenship behavior. Temuan ini menunjukkan bahwa spirituality yang muncul dari aspek individu belum bisa menciptakan seorang profesional untuk mementingkan orang lain, menuruti kata hati, bersikap sportif, dan mementingkan kepentingan umum. Disamping itu, individual spirituality bagi para profesional juga belum bisa meningkatkan kerjasama dalam bekerja, bekerja secara kreatif, bekerja keras, dan komitment terhadap pekerjaan.

Untuk meningkatkan OCB bagi para profesional, maka dapat disampaikan beberapa saran sebagai berikut: pada variabel organizational spirituality berdasarkan pada hasil deskriptif statistik, indikator keterlibatan pada kegiatan-kegiatan keagamaan yang lain memiliki nilai yang rendah. Temuan ini perlu mendapatkan perhatian bagi para profesional, karena memiliki peran penting dalam meningkatkan $\mathrm{OCB}$, sehingga perlu pemahaman bahwa kegiatan-kegiatan keagamaan yang terkait secara langsung dengan profesi akan sangat berguna bagi pengembangan para professional. Sementara itu terkait dengan Islamic Work Ethics, maka peningkatan OCB dapat dilakukan dengan bekerja lebih serius dan keras. Disamping itu juga perlu adanya efektivitas dalam konsultasi pekerjaan dengan melibatkan rekan kerja pada setiap pekerjaan.

Hasil studi ini perlu dikembangkan dengan menambah variabel yang dimungkinkan dapat meningkatkan organizational citizenship behavior, misalnya: knowledge sharing behavior employee engagement, dan spiritual motivation. Selain itu pengembangan studi dapat menggunakan responden yang lebih spesifik, dan dengan jangkauan yang lebih luas. 


\section{DAFTAR PUSTAKA}

Achour, M., Grine, F., Roslan, M., \& Nor, M. (2015). Measuring Religiosity and Its Effects on Personal Well-Being: A Case Study of Muslim Female Academicians in Malaysia. Journal of Religion and Health, 984-997. https://doi.org/10.1007/s10943-014-9852-0

Arabi, S. H. (2016). Well-being orthodox theories and Islamic views. International Journal of Social Economics, 43(2), 190-204. https://doi.org/10.1108/IJSE-01-2013-0019

Arshad, M. (2011). interdisciplinary journal of contemporary research in business, 1160 1170.

Ashmos, D. P., \& Duchon, D. (2000). Spirituality at Work: A Conceptualization and Measure. Journal of Management Inquiry, 9(2), 134-145. https://doi.org/10.1177/105649260092008

Chen, C. Y., \& Yang, C. F. (2012). The Impact of Spiritual Leadership on Organizational Citizenship Behavior: A Multi-Sample Analysis. Journal of Business Ethics, 105(1), 107-114. https://doi.org/10.1007/s10551-011-0953-3

Chen, Y. S. (2008). The positive effect of green intellectual capital on competitive advantages of firms. Journal of Business Ethics, 77(3), 271-286. https://doi.org/10.1007/s10551006-9349-1

Fiorillo, D., \& Nappo, N. (2014). Job satisfaction in Italy: individual characteristics and social relations. International Journal of Social Economics, 41(8), 683-704. https://doi.org/10.1108/IJSE-10-2012-0195

Fry, L. W., \& Cohen, M. P. (2009). Spiritual leadership as a paradigm for organizational transformation and recovery from extended work hours cultures. Journal of Business Ethics, 84(SUPPL. 2), 265-278. https://doi.org/10.1007/s10551-008-9695-2

Fry, L. W., Vitucci, S., \& Cedillo, M. (2005). Spiritual leadership and army transformation: Theory, measurement, and establishing a baseline. Leadership Quarterly, 16(5), 835862. https://doi.org/10.1016/j.leaqua.2005.07.012

Gupta M, Kumar V, and Si. M. (n.d.). Creating Satisfied Employees Through Workplace Spirituality.pdf.

Gupta M. Kumar V, and Singh M. (2014). Creating Satisfied Employees Through Workplace Spirituality: A Study of the Private Insurance Sector in Punjab (India). J Bus Ethics (2014) 122:79-88; DOI 10.1007/s10551-013-1756-5

Karakas, F. (2010). Spirituality and performance in organizations: A literature review. Journal of Business Ethics, 94(1), 89-106. https://doi.org/10.1007/s10551-009-0251-5

Kaya, A. (2015). The Relationship between Spiritual Leadership and Organizational Citizenship Behaviors: A Research on School Principals' Behaviors. Educational Sciences: Theory \& Practice, 15(3), 597-607. https://doi.org/10.12738/estp.2015.3.1988

Khan, K., Abbas, M., Gul, A., \& Raja, U. (2013). Organizational Justice and Job Outcomes: Moderating Role of Islamic Work Ethic. Journal of Business Ethics, 126(2), 235-246. https://doi.org/10.1007/s10551-013-1937-2 
Kolodinsky, R. W., Giacalone, R. A., \& Jurkiewicz, C. L. (2008). Workplace values and outcomes: Exploring personal, organizational, and interactive workplace spirituality. Journal of Business Ethics, 81(2), 465-480. https://doi.org/10.1007/s10551-007-9507-0

Kutcher, E. J., Bragger, J. D., Rodriguez-srednicki, O., \& Masco, J. L. (2010). The Role of Religiosity in Stress , Job Attitudes , and Organizational Citizenship Behavior, 319-337. https://doi.org/10.1007/s10551-009-0362-z

Milliman, J., Czaplewski, A. ., \& Ferguson, J. (2003). Workplace spirituality and Employee Work Attitudes - An Exploratory Empirical Assessment. Journal of Organizational Change Management, 16(4), 426-447. https://doi.org/10.1108/09534810310484172

Mitroff, I. A., Denton, E. A., \& Alpaslan, C. M. (2009). A Spiritual Audit of Corporate America: Ten Years Later, 1-27.

Pawar, B. S. (2009). Workplace spirituality facilitation: A comprehensive model. Journal of Business Ethics, 90(3), 375-386. https://doi.org/10.1007/s10551-009-0047-7b

Pawar, B. S. (2014). Leadership Spiritual Behaviors Toward Subordinates: An Empirical Examination of the Effects of a Leader's Individual Spirituality and Organizational Spirituality. Journal of Business Ethics, 122(3), 439-452. https://doi.org/10.1007/s10551-013-1772-5

Rokhman, W., \& Hassan, A. (2012). The effect of Islamic work ethic on organisational justice. African Journal of Business Ethics, 6(1), 25. https://doi.org/10.4103/18177417.104699

THe Relationship Between Spirituality And Job Satisfact Ion By Freda Van Der Walt Submitted in partial fulfilment of the requirements for the Degree DOCTOR OF PHILOSOPHY ( PhD ) In Organizational Behaviour in the Faculty of Eco. (2007), (April).

Underwood, L. G. (2011). The Daily Spiritual Experience Scale: Overview and Results, 2950. https://doi.org/10.3390/rel2010029

Yousef, D. A. (2000). Organizational commitment as a mediator of the relationship between Islamic work ethic and attitudes toward organizational change. Human Relations, 53(4), 513-537. https://doi.org/10.1177/0018726700534003 